\title{
Impact of Gas Production, Utilization and Flaring on Economic Growth: Evidence from the Republic of Congo
}

\author{
Prince Valdano Itoua1 ${ }^{*}$, Durell Esperance Ndinga Manguet ${ }^{2}$, Gilhaimé Mouanda-Mouanda ${ }^{3}$ \\ ${ }^{1}$ School of Economics and Management, North China Electric Power University, Beijing, China \\ ${ }^{2}$ School of Management and Economics, Hubei University of Technology, Wuhan, China \\ ${ }^{3}$ School of Economics, Henan University, Kaifeng, China \\ Email: *princeitoua@yahoo.fr
}

How to cite this paper: Itoua, P. V., Manguet, D. E. N., \& Mouanda-Mouanda, G. (2021). Impact of Gas Production, Utilization and Flaring on Economic Growth: Evidence from the Republic of Congo. Open Journal of Business and Management, 9, 1492-1509.

https://doi.org/10.4236/ojbm.2021.93080

Received: April 19, 2021

Accepted: May 28, 2021

Published: May 31, 2021

Copyright $\odot 2021$ by author(s) and Scientific Research Publishing Inc. This work is licensed under the Creative Commons Attribution International License (CC BY 4.0).

http://creativecommons.org/licenses/by/4.0/

\section{(c) (i) Open Access}

\begin{abstract}
The purpose of this study is to investigate the impact of the gas production, gas use and gas flaring on economic growth of the Republic of Congo during the period 2006-2019. The results of the unit root test reveal that the bulk of variables are stationary at level and therefore integrated of order zero, however, labor input which is stationary at first difference and integrated of order one. The test of Johansen cointegration shows that all time series are cointegrated and have a long-run equilibrium relationship. We also perform the Granger-causality test which proves that only gas production and gas utilization cause economic growth in our study. The OLS regressions suggest gas production impacts adversely and significantly GDP while gas utilization significantly stimulates GDP.
\end{abstract}

\section{Keywords}

Gas, Economic Growth, Time Series, Cointegration Test, Unit Root Test, Republic of Congo

\section{Introduction}

The development strategies of many countries are often based on natural resources such as minerals, oil and natural gas.

Following this, several researchers have carried out research on this subject such as: Karl (1997) said that oil and gas play an important role in the development strategy (economic growth) of a country. Some researchers have proven the opposite by saying the presence of natural resources has a positive and nega- 
tive impact on the growth of a country, the case of researchers Ross (1999), who established a theory of the resource curse, a theory which explains that if the countries rich in resources but with a low growth rate, unlike countries poor in resources with high growth; Nankani (1980); Sachs and A.M. Warner (1997); Wheeler (1984). Prebisch (1950); Singer (1950); Nurske (1958) say that the inability of natural resource industries to induce growth cannot be suppressed among resource extraction industries by foreign investors who prefer to repatriate their profits instead of reinvesting, Hirschman (1958). There is also a suggestion of a positive association between resource extraction and the collapse of law and order. Ross (1999); Reno (1995) are apart from these observations.

Unlike the paragraph below, the abundance of natural resources can have consequences such as the real exchange rate of the currency, which can reduce exports of manufactured goods and services (Corden, 1982); they can give people a false sense of security and cause governments to lose sight of the need for quality, growth-friendly economic management, including free trade, bureaucratic efficiency, institutional quality and sustainable development (Sachs \& Warner, 1997). This has effects on economic growth, despite little attention has been given to this topic on the Republic of Congo. As far as we know, this study is the first attempt focusing only on this Central Africa's gas country. In Indexmundi Data (2019), the republic of Congo occupies is ranked 8th in Africa terms of worldwide in gas reserves. Because of the major role of this sector for the economic development, the purpose of this study is to bridge that gap. But actually the Congolese government aims to correct imbalances in the management (production, utilization and flaring) of oil and gas through the implementation of the decisions taken at the World Conference on Climate Change (COP21): with the aim of slowing down and to contain the increase in the world's average temperature to less than $2^{\circ} \mathrm{C}$, most of which is caused by natural gas flaring (Afrik.com); the implementation of decree 2007-294 prohibits the systematic combustion of natural gas in all oil and gas installations, as well as the development of a new hydrocarbons code $n^{\circ}$ 2016-28, section 2-Associated gas flaring: Article 136. The flaring of associated gas, with the exception of flaring carried out in the context of tests, safety or other occasional oil works according to the rules of the art generally accepted in the international hydrocarbon industry, is prohibited without authorization of special preliminary from the Minister in charge of hydrocarbons issued in accordance with the regulations in force. Despite the difficulties encountered more precisely, the lack of documents dealt with the impact of the three variables (production, utilization and flaring of gas) on economic growth at the national and international. The remaining of this paper is organized as follows: Section 2 reviews the literature; Section 3 presents natural gas resource; Section 4 considers Gas flaring in Republic of Congo and comparison with Global Trend; Section 5 reports major motivators of gas flaring; Section 6 describes health, environmental and economic impacts of flared gas; Section 7 refers to valorization of gas; Section 8 presents the methodology 
used (Time series unit root test, cointegration test, Granger causality, Empirical estimation); Section 9 is conclusion and Recommendations.

\section{Literature}

Regarding the impact of gas production, utilization and flaring on economic growth, there are not enough empirical studies in the literature review so our literature review will be based on the difficulties faced by countries which have abundant natural resources and the relationship that exists between gas produced, consumed (used) and gas flaring on economic growth.

Firstly, Frankel (2010) this can be caused by six main reasons which are as follows: 1) The prices of natural resources can be subjected to substantial declines in world markets; 2) Natural resources can be unfavorable sectors as they can crowd out the manufacturing sector; 3) The volatility of world prices for natural resources, which sometimes tends to be higher, could have implications for the economy; 4) Countries where the control of oil, natural gas or other resources by government or certain companies may confer wealth and be less likely to develop the institutions necessary for economic development; 5) These countries may have armed conflicts or wars, this negatively impacts economic growth or development; 6) Price fluctuations can cause excessive macroeconomic instability, through the real exchange rate and government spending, imposing unnecessary costs. It should be said that the abundance of natural resources have advantages and disadvantages Frankel (2010). Sachs and Warner (1995); Sachs and Warner (1995); Ross (2001), Sala-i-Martin and Subramanian (2003), Smith (2004); Smith (2004) show that natural resources (oil) can have a negative effect on a country's economy. These record, Delacroix (1977); Davis (1995) and Herb (2005) say no evidence of the negative effects of natural resources while Alexeev and Conrad (2009) demonstrates that oil and mineral wealth have positive effects on per capital income, when controlling for a number of variables for East Asia and Latin America. Philippot (2010) demonstrated the positive effects of natural resources on the economic growth of economies in transition, while Michaels (2007) examined different channels through which abundance of resources can hamper economic growth and infer the wealth of resources. It did not delay economic development in the southern United States, but rather served as an important source for economic development as well Tompson (2006) asserts.

Secondly, the impact of gas consumption can have a direct or indirect relationship with economic growth. To this end, in Fadiran, Adebusuyi, \& Fadiran (2019). Fadiran, Adebusuyi and D. Fadiran carried out studies on natural gas consumption and economic growth in 2019 based on data from twelve (12), to carry out the panel co-integration analysis and from the vector correction model, resustat found the existence of a long-term relationship between natural gas consumption and economic growth. But the non-existence of a short-term relationship and the variables used are gross variable fixed capital formation, labor 
force, trade openness and real GDP. The production of natural gas and economic growth have a long-term co-integrated relationship. This was tested by Songur, Muratoglu, \& Muratoglu (2016) during a study done on the relationship between natural gas production and per capita GDP income for the following countries: Azerbaijan, Russian Federation, Kazakhstan, Turkmenistan and Uzbekistan. The result obtained shows that energy production has an important role. Consumption increases with production. To this, it would be better to suggest to these countries to adopt the policies of increasing their production of natural gas, such as increased investments in infrastructure. Mastorakis and Yazdi (2014) Mastorakis \& Yazdi examined the causality between gas consumption and economic growth in Iran. They used an autoregressive distributed shift and the results show that gas consumption contributes to economic growth. Işik (2010) Işik studied the effect of gas consumption and economic growth in Turkey. The results show that the consumption of natural gas has a positive effect on the Turkish economy in the short term but rather a negative effect in the long term. Given the gas made from energy, in order to broaden the research we have summarized existing research on the relationship between energy consumption and economic growth. To see the impact of consumption of energy on economic growth, Oh and Lee (2004) argued that in particular for distinguishing short-term relationships from long-term dynamics, empirical results suggest that multivariate VECM models may be useful for examining Granger causality in the presence of co-integration. They found the existence of a long-term one-way causal relationship between gross domestic product (GDP) and energy, but no short-term causal relationship between energy and GDP. Paul and Bhattacharya (2004) who examined the causal relation between the consumption of energy and economic growth in India, using the Engle-Granger co-integration method combined with the standard Granger causality test of 1950-1996, the result obtained shows the existence of a bidirectional causality between energy consumption and economic growth. Next, Johansen's multivariate co-integration technique was applied to the different sets of variables. The same sense of causality exists between energy consumption and economic growth. As well as the existence of a unidirectional causal relationship between energy consumption and economic growth, following empirical results obtained based on the standard Granger causality test. That is, no causal impact from economic growth to energy consumption. Both hard, the application of the Engle-Granger co-integration approach was not noticed by any short-term, long-term one-way causality between GDP and capital to energy consumption. In conclusion, the combined Engle-Granger results for the Granger Standard Causality show that there is a two-way causality between energy consumption and economic growth. And the long-term causal relationship is from GDP to energy consumption and the short-term causal relationship is the reverse, in other words, from energy consumption to GDP. Studies on the causal relationship between several types of industrial energy consumption and real GDP in Shanghai for 1952-1999 were 
carried out by Wolde-Rufael (2004), The empirical results show that there was a unidirectional Granger causality of coal, coke, electricity, and total energy consumption to real GDP except oil consumption. In Turkey, the existence of a strong long-term causality of energy consumption to real GDP following the studies of Altinay and Karagol (2005). In conclusion the existence of a causal relationship between the variables. Soytas and Sari (2003) show that there is causality going from GDP to energy consumption in countries such as: in Italy and Korea, and from energy consumption to GDP in Turkey, France, Germany and in Japan. But a two-way causality in Argentina. Lise and Montfort (2007) have shown that the causality goes from income to long-term energy consumption. In Turkey over the period 1968 to 2005, Halicioglu (2007) endorsed the income and price elasticity of residential energy demand in both the short and long term. The existence of a two-way Granger causality between energy consumption and real GDP has been demonstrated by Bowden and Payne (2008). Soytas and Sari (2007) studied causality in Turkey in an emerging market, between energy more precisely electricity consumption and the output of Turkish manufacturing at the industry level. Research done by Lee and Chang (2007) to see if there is a relationship between energy consumption and real GDP in 22 developed and 18 developing countries, have shown that a one-way causality between real GDP and energy consumption in developing countries, but the existence of a two-way causality between energy consumption and real GDP in developed countries Akan, Dogan and Is1k (2010). The long-term relationship between total energy consumption and some major economic factors such as the price of energy has been examined by Wei (2002), income and the share of heavy industry in GDP and found that energy consumption and the main variables are co-integrated Akan, Dogan and Isık (2010). Studies carried out in a few countries in Sub-Saharan Africa show that: Ebohon (1996) using the classic Granger test on Tanzania and Nigeria, finds a two-way causality between economic growth and energy consumption for these two countries. Wolde (2005), studying the African countries of the West African Economic and Monetary Union (UEMOA) finds over the period 1971-2002, a causality of energy consumption towards economic growth for Benin, and the meaning reverse for Senegal. Mawussé (2009) analyzing the relationship between energy consumption and GDP growth in UEMOA countries, finds that in the long term, oil consumption has a positive and significant impact on national income in all the countries studied except Togo. Bartleet and Gounder (2010) have shown the existence of a causality from economic growth to energy consumption for Nigeria. Mensah (2014) examining the relationship between energy consumption and economic growth finds a unidirectional causality of energy consumption to economic growth in Kenya, while this relationship is reversed for Ghana. Ouedraogo (2010); Kouakou (2011) respectively find a two-way causality between economic growth and energy consumption for Burkina Faso and Ivory Coast. Other authors have broken down GDP into its main components to study the link between economic growth and ener- 
gy consumption. Kebede et al. (2010) found that the demand for energy is driven by the growth of agriculture's share of GDP while the relationship is the opposite when it comes to industry's share of GDP. Jebli et al. (2014) found a causal link from trade (exports or imports) to the consumption of renewable energy. Finally, applying the causality test in the sense of Granger for the same country, some authors have reached divergent results because of the divergence between the study periods, the failure to consider certain political changes or economic activities in these countries, of the functional form etc. without however calling into question the methodology as a whole. Different methods have been carried out and the results have been analyzed in this literature review which examines the existing relationships between the production or abundance of natural resources, energy consumption as well as the consumption of natural gas on the economic growth of a country. This literature review will allow us to carry out our study on Impact of gas production, utilization and flaring on economic growth.

\section{Natural Gas Resource}

The information from Statistical Review of Word Energy (2020), allowed us to establish Table 1, which is the summary of gas reserves and volumes of gas produced in Africa in 2019 in Indexmundi Data (2019) and Ministry of Hydrocarbons (2020). In 2019, the Republic of Congo occupies is ranked $8^{\text {th }}$ over 53 in Africa in terms of worldwide in gas reserves: of around $90 \mathrm{bcm}$ and production of around $7.659 \mathrm{bcm}$, as shown in the table below.

Proved Reserves of oil and gas are the quantities the information indicated by technical geologists with reasonable certainty, they can be recovered in the future from known reservoirs under existing economic and operating conditions. Indeed, reserves over production (RP) is the ratio to find the length of time these remaining reserves would last if production were to continue at a constant rate (BP, 2012).

Table 1. Natural gas proved reserves and production in 2019.

\begin{tabular}{cccccc}
\hline \multirow{2}{*}{ country } & \multicolumn{2}{c}{ proved reserves } & \multicolumn{2}{c}{ gas production } & ratio \\
\cline { 2 - 5 } & $\begin{array}{c}\text { trillion cubic } \\
\text { metres (tcm) }\end{array}$ & $\begin{array}{c}\text { share of } \\
\text { total (\%) }\end{array}$ & $\begin{array}{c}\text { billion cubic } \\
\text { meters (bcm) }\end{array}$ & $\begin{array}{c}\text { share of } \\
\text { total (\%) }\end{array}$ & $\begin{array}{c}\text { R/P } \\
\text { Algeria }\end{array}$ \\
Egypt & 4.3 & 2.2 & 86.2 & 2.2 & 50.3 \\
Libya & 2.1 & 1.1 & 64.9 & 1.6 & 32.9 \\
Nigeria & 1.4 & 0.7 & 9.4 & 0.2 & 151.5 \\
Other Africa & 5.4 & 2.7 & 49.3 & 0.7 & 58.1 \\
Total Africa & 57.5 & 0.8 & 28 & 6 & 62.7 \\
Total World & 527 & 7.5 & 237.9 & 100 & 49.8 \\
\hline
\end{tabular}

Source: Statistical Review of Word Energy 2020. 


\section{Gas Flaring in Republic of Congo: A Comparison with Global Trend}

In 2019, the global gas torch volume increased to 150 billion cubic meters $(\mathrm{bcm})$, which corresponds to the annual growth consumption of sub-Saharan Africa, with the growth rate of 3\%, 145 billion cubic meters (bcm) in 2018 to $150 \mathrm{bcm}$ in 2019 , due to increases in three countries: the United States $(+23 \%)$, including the $20 \%$ increase in oil production; Venezuela $(+16 \%)$, with a drop in oil production of nearly 40\%; and Russia (+9\%), with stable oil production. Gas flaring in conflict-affected countries for a period from 2018 to 2019 has increased: in Syria by $35 \%$ and in Venezuela by $16 \%$, although oil production has remained stable in Syria and has declined by $40 \%$ in the past in Venezuela. The top four gas flaring countries (Russia, Iraq, US and Iran) continue to account for nearly half (45\%) of all global flares for three consecutive years (2017-2019), suggesting that there may be obstacles to reducing gas flaring practices in these countries Word Bank (2020).

Figure 1 is the representation for a period going from 2015 to 2019, of the five (5) first world countries to collect gas, associated with the republic of the congo which occupies the 17th place in the world with respective values: $0.872 \mathrm{bcm}$ in $2015 ; 0.693 \mathrm{bcm} ; 0.682 \mathrm{bcm}$ in 2017; $0.837 \mathrm{bcm}$ in 2018 followed by $0.961 \mathrm{bcm}$ in 2019. Indeed, these five (5) first gas torch countries which are: Russia, Iraq, United States, Iran, and Venezuela.

\section{Major Motivators of Gas Flaring}

While gas flaring can be carried out as a precautionary measure in oil exploration and production fields platforms, unregulated flaring could have dire consequences. Gas flaring occurs for several reasons. In the views of (Total, n.d.) this could be due to safety reasons where gas is burned in order to relieve pressure on the system in an emergency or during maintenance; or as part of a quality assurance procedure during well testing or new plant start-ups, where gas is flared until gas with the required properties (for transport or reuse) is got. Reference Elvidge et al. (2009) consider that one of the main reasons for continued gas flaring is the lack of infrastructure which makes it impossible to commodity gas.

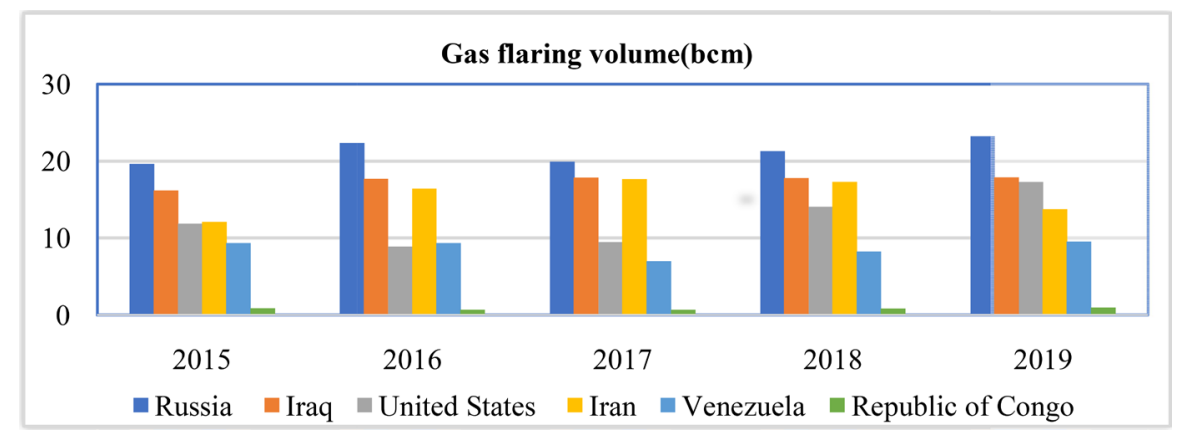

Source: Data from Word Bank (2020); Ministry of Hydrocarbons (2020).

Figure 1. Representation of flue gases from some countries of the world. 
This category of continuous flaring represents the most important quantities.

Figure 2, illustrates the volumes of gas produced, used and burned in the Republic of Congo from 2010 to 2019. Regarding the volumes of gas produced, a minimum of $6.131 \mathrm{bcm}$ was observed in 2013 for a maximum of $7.659 \mathrm{bcm}$ in 2019 ; i.e. a variation of $1.528 \mathrm{bcm}$. For the volumes of gas used, the minimum is $4.973 \mathrm{bcm}$ in 2010 for a maximum of $6.698 \mathrm{bcm}$ in 2019; i.e. a variation of 1.725 $\mathrm{bcm}$. Finally, for gas torches, we have a minimum of $0.682 \mathrm{bcm}$ in 2017 and a maximum of $1.631 \mathrm{bcm}$ in 2010 ; i.e. a variation of $0.949 \mathrm{bcm}$.

\section{Health, Environmental and Economic Impacts of Flared Gas}

For Public Health, flaring leads to incomplete combustion of hydrocarbons, leading to all kinds of harmful compounds; if natural gas also contains $\mathrm{CO}_{2}, \mathrm{H}_{2} \mathrm{~S}$ or other impurities, then this effect is much greater (Canadian Public health). The effects concern both human populations and agriculture (acid rain, heavy metals); Nigerian communities located near the flares complained (Nigeria Gas Flaring Wrecking Delta Communities).

In terms of the environment, the emission of smoke and carbon dioxide $\left(\mathrm{CO}_{2}\right)$ are the main causes of greenhouse gases (GHGs). The flame and the light it emits can be a source of light pollution and disturb the night environment, in particular by causing ecological trap situations for certain species, which can have indirect consequences in the case of pollinators when they come in mass burn in the flame. Among the examples illustrating the UN Global Taxonomic Initiative project, initiated within the framework of the implementation of the Convention on Biological Diversity (CBD), the CBD Secretariat cites (Secretariat of the Convention on Biological Diversity) in this regard the next example "Members of a family of moths, called 'sphinxes,' pollinate various trees and plants in the forests. Each species of these moths pollinates a single plant species, which is to say that if a particular type of butterfly is absent the plants that depend on it cannot be pollinated and therefore cannot reproduce. Recently, a

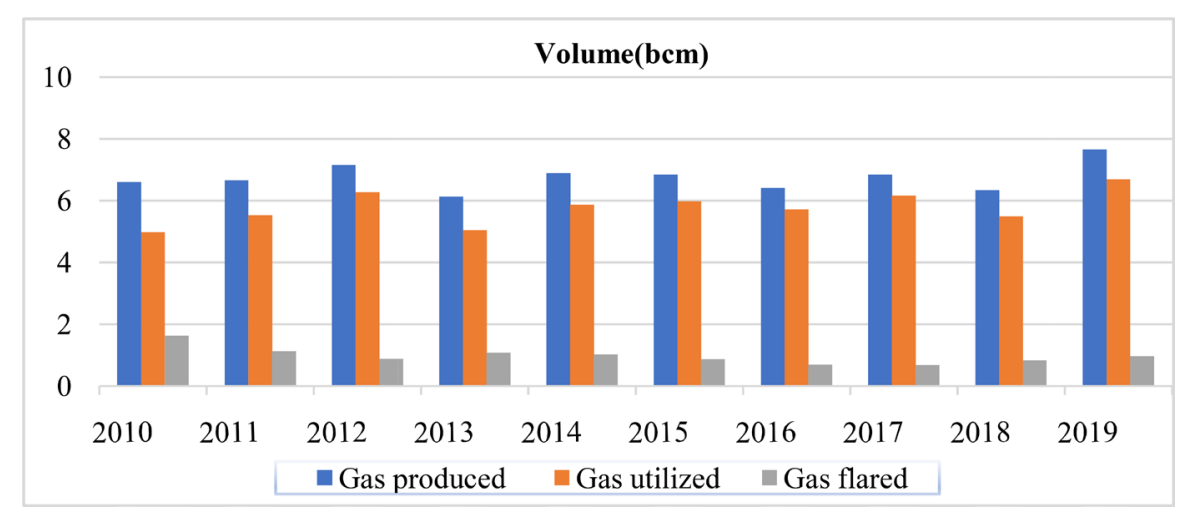

Source: Data from Ministry of Hydrocarbons (2020).

Figure 2. Ten-year trend of natural gas produced, used and flared in Congo (2010-2019). 
taxonomist working in a tropical forest noticed that a torch from a nearby oil refinery attracted and killed these moths in hundreds. Considering the number of years since the operation of this refinery, one can easily estimate the large number of moths killed, and the number of unpollinated plants given the vast area of the forest. Without being able to say what these butterflies were, this important information could not have been accessed and no remedial action was taken (Secretariat of the Convention on Biological Diversity). Next, in terms of Economic Effects, the gas surge also has blatant repercussions on a nation's economy, in terms of the loss of funds and income that it could have reassessed had it kept gas as instead of igniting. Nigeria provides a dreadful example of such a loss. Oil companies in Nigeria flare an estimate of 2.5 billion cubic feet of gas every day and this action amounts to lost revenue, estimated at 2.5 billion US dollars per year Collins and Oshodi (2010).

From an economic point of view, the eruption of this associable gas is a colossal waste for the communities; the economic cost of the soaring total gas is quite staggering, which implies great investment possibilities for the private sector. Therefore, more gas-intensive modes of production, greater private sector investment are encouraged in the sector and governments should recycle and seek more business opportunities for the gas sector Madueme (2010). Releasing greenhouse gases into the atmosphere, gas flares are said to release approximately 45.8 billion kilowatts of heat into the atmosphere of the Niger Delta from gases flaring daily. As a result of this environmental incineration, the combustion of gas raised temperatures and made large areas uninhabitable Augustine and Sanford (1976).

\section{Valorization of Gas}

Notwithstanding the above statistics and their consequences, the argument has not been whether the associated gas should be flared, but rather how to best use the associated natural gas and/or regulate its disposal. There is a business case for proper development and use of associated natural gas, as it can be a source of considerable foreign exchange Akpan (2009). The associated offshore gas could be economically processed, recovered and used in power generation Hill et al. (1985). This view is supported by the results of the study which suggests that substantial sums could be saved if conventional fuel and energy were replaced by natural gas. It could also reduce the level of loss reported by Energy Sector Management Assistance Program (2001).

\section{Methodology}

The data used in this topic come from data obtained from secondary sources from different sources. The data collection process looks like this: First collection of natural gas resource data (Natural gas proved reserves and production in 2019) from a few African countries from Statistical Review of Word Energy 
(2020) and Indexmundi Data (2019). Secondly acquisition of gas production (GSP), gas use (GSU) and gas flaring (GSF) data for the Republic of Congo comes from the Direction of exploration and exploitation of the Ministry of Hydrocarbons, 2020 and some word countries gas flaring from Word Bank (2020). Thirdly, the data on gross domestic product (GDP), gross fixed capital formation (GCF) and stock of labor (LBR) in Congo are from World Bank Global Development. Table 2 exhibits descriptive statistics of each variable used in this study.

\subsection{Time Series Unit Root Test}

Unit root test enables to check whether time series data are stationary or not. Because the non-stationary status or the presence of unit root leads to spurious or biased results. The autoregressive model AR (1) to implement unit root test is presented as follows:

$$
Y_{t}=\theta Y_{t-1}+\omega_{t}
$$

After taking the first difference, the model can be formulated as:

$$
\Delta Y_{t}=(\theta-1) Y_{t-1}+\omega_{t}=\pi \ln Y_{t-1}+\omega_{t}
$$

where $\Delta Y_{t}$ and $Y_{t-1}$ represent respectively the first difference and the one-period lag of every single time serie; $\omega_{t}$ is the white noise error term. By considering $\pi=(\theta-1)$, the unit root hypothesis translates into: $H_{0}: \pi=0$ (non-stationary or unit root) and $H_{A}: \pi<0$ (stationary). In our paper, we apply the Augmented Dickey-Fuller (ADF) unit root test. The rule of thumb suggests that the null hypothesis $\left(H_{0}\right)$ is rejected if the test statistic is greater than the critical value at $5 \%$ in absolute value.

Table 3 presents the results of the Augmented Dickey-Fuller unit root test. With the exception of labour input (LBR), we observe that the remaining time series are all stationary at level because the test statistic is larger than the critical value, both in absolute value. This suggests that GDP, GSP, GSF, GSU and GCF are all integrated of order zero: I (0). By contrast, LBR becomes stationary at first difference and therefore integrated of order one: $I(1)^{1}$.

Table 2. Descriptive statistics.

\begin{tabular}{cccccc}
\hline Variables & Observations & Mean & Std.dev. & Minimum & Maximum \\
\hline $\begin{array}{c}\text { gross domestic product (GDP) } \\
\text { gross fixed capital formation (GCF) }\end{array}$ & 14 & 23.25 & 0.14 & 22.99 & 23.40 \\
gas production (GSP) & 14 & 21.68 & 0.43 & 21.03 & 22.32 \\
gas use (GSU) & 14 & 22.60 & 0.13 & 22.21 & 22.76 \\
gas flaring (GSF) & 14 & 22.06 & 0.25 & 21.30 & 22.35 \\
stock of labor (LBR) & 14 & 20.68 & 0.34 & 20.07 & 21.44 \\
\hline
\end{tabular}

Source: Authors' calculations. All variables are in logarithm. Std.dev. stands for standard deviation.

${ }^{1}$ We do no report the Augmented Dickey-Fuller unit-root test at first difference for LBR. 


\subsection{Cointegration Test}

The cointegration test examines the existence of a long-run equilibrium relationship between two variables. We only focus on integrated time series of order zero. For this purpose, we perform the Johansen test for cointegration and the results are presented in Table 4.

Table 3. Augmented dickey-fuller (ADF) unit-root test.

\begin{tabular}{ccccccc}
\hline variable at level & GDP & GSP & GSF & GSU & GCF & LBR \\
\hline coefficient & $-0.18^{* * *}$ & $-0.79^{*}$ & 00.98 & $-0.66^{* * *}$ & $-0.36^{*}$ & 0.01 \\
standard error & $(0.049)$ & $(0.25)$ & $(0.43)$ & $(0.18)$ & $(0.19)$ & $(0.009)$ \\
test-statistic & -3.64 & -3.11 & -2.28 & -3.55 & -1.87 & 1.02 \\
critical value (5\%) & -1.83 & 1.83 & 1.83 & 1.83 & 1.83 & 1.83 \\
\hline
\end{tabular}

Note: All variables are in logarithm. We include drift term in ADF unit root test. ${ }^{* *},{ }^{\star *}$ and ${ }^{*}$ denote respectively significance level at $1 \%, 5 \%$ and $1 \%$.

Table 4. Johansen test for cointegration.

\begin{tabular}{cccc}
\hline variables & max. rank & trace statistic & critical value (5\%) \\
\hline \multirow{2}{*}{ GDP and GSP } & 0 & 28.52 & 15.41 \\
GDP and GSF & 1 & 4.27 & 3.76 \\
GDP and GSU & 0 & 45.92 & 15.41 \\
GDP and GCF & 1 & 8.56 & 3.76 \\
& 1 & 23.92 & 15.41 \\
GSP and GSF & 0 & 4.99 & 3.76 \\
& 1 & 16.19 & 15.41 \\
GSP and GSU & 0 & 2.67 & 3.76 \\
& 1 & 18.42 & 15.41 \\
GSP and GCF & 0 & 6.72 & 3.76 \\
& 1 & 19.23 & 15.41 \\
GSF and GSU & 0 & 7.35 & 3.76 \\
GSF and GCF & 1 & 30.36 & 15.41 \\
& 1 & 7.9 & 3.76 \\
GSU and GCF & 0 & 50.1 & 15.41 \\
& 1 & 5.17 & 3.76 \\
\hline
\end{tabular}

Note: All variables are in logarithm.

As shown in Table 4, the null hypothesis of no cointegration equation is rejected because the value of trace statistic is higher than the critical value. This means that there is at least one cointegrating relationship between every biva- 
riate model. In other words, the results prove the existence of a long-run equilibrium relationship among all integrated variables of order zero.

\subsection{Granger Causality}

The test of Granger causality enables to determine whether one time series is useful for forecasting another. The results displayed in Table 5 shows that GDP does not Granger-cause GSP, GSF, GSU and GCF. Likewise, GSF (gas flaring) and GCF (gross capital formation) do not Granger-cause GDP. By contrast, we find that GSP (gas production) and GSU (gas use) do Granger-cause GDP because the probability is less than 0.05 .

\subsection{Empirical Estimation}

Based on the paper of Energy sector management assistance program, we regress the following equation ${ }^{2}$ :

$$
\ln G D P_{t}=\alpha_{0}+\alpha_{1} \ln G S P_{t}+\alpha_{2} \ln G S U_{t}+\alpha_{3} \ln G S F_{t}+\beta_{1} \ln G C F_{t}+\mu_{t}
$$

where $\ln G D P_{t}$ is the $\log$ of output proxied by GDP of Congo; $\ln A$ is the $\log$ of technical efficiency or total factor productivity; $\ln G S P_{t}$ is the log of the volume of gas produced; $\ln G S P_{t}$ is the log of the volume of gas utilized; $n G S F_{t}$ is the $\log$ of the volume of gas flared; $\ln G C F_{t}$ is the log of capital input proxied by gross capital formation; $\alpha_{1}, \alpha_{2}$ and $\alpha_{3}$ are the estimation parameters respectively associated with the impact of gas production, gas utilization and gas flaring on economic growth in Congo; $\beta_{1}$ is the estimated coefficient associated with the influence of capital input on economic growth in Congo; $\mu$ is the disturbance term; $t$ denotes the time period of the study from 2006 to 2019 .

In Table 6, we present the results of Ordinary Least Square (OLS) regressions. In column (1), it is shown that R-squared is 0.60 . This means that the explanatory variables explain $60 \%$ of the variation of this model. The regressions reveal

Table 5. Granger causality Wald tests.

\begin{tabular}{ccc}
\hline & chi $^{2}$ & Prob $>$ chi $^{2}$ \\
\hline GDP $--->$ GSP & 1.14 & 0.28 \\
GSP ---> GDP & 14.47 & 0.00 \\
GDP ----> GSF & 1.60 & 0.20 \\
GSF ---> GDP & 0.95 & 0.32 \\
GDP ---> GSU & 0.49 & 0.48 \\
GSU ---> GDP & 24.94 & 0.00 \\
GDP $--->$ GCF & 0.46 & 0.49 \\
GCF $--->$ GDP & 2.52 & 0.11
\end{tabular}

Note: All variables are in logarithm.

${ }^{2}$ In this regression model, we only consider stationary variables integrated at order zero. Thus, labour input (LBR) is excluded. Stata 14 is used to perform the regression. 
Table 6. OLS regressions.

\begin{tabular}{ccc}
\hline dep. variable: GDP as proxy of economic growth & \\
\hline gas production (GSP) & $(1)$ & $(2)$ \\
gas use (GSU) & -0.56 & $-0.98^{\star *}$ \\
& -0.6 & -0.41 \\
gas flaring (GSF) & $0.67^{\star}$ & $0.74^{\star * \star}$ \\
& -0.3 & -0.21 \\
gross formation capital (GCF) & 0.088 & 0.15 \\
& -0.18 & -0.128 \\
R-squared & 0.018 & 0.064 \\
observations & -0.08 & -0.08 \\
\hline
\end{tabular}

Note: All variables are in logarithm. In column (2), we use one-period lag of explanatory variables. ${ }^{* *},{ }^{* *}$ and ${ }^{*}$ denote the level of significance respectively at $1 \%, 5 \%$ and $10 \%$. Robust standard errors in parentheses are clustered by year.

that the coefficient of GSP is not significant and displays a negative sign. This implies that there is no economic meaning of gas production. When we examine GSU, its coefficient is positive and significant at the $10 \%$ level. This suggests that a $1 \%$ increase in gas utilization promotes economic growth by $0.67 \%$. The two remaining variables, i.e., GSF and GCF, have positive coefficients but insignificant.

Generally, OLS regressions provide inconsistent and biaised results due to endogeneity problem (e.g. reverse causality, omitted variables). To deal with this concern, the simplest way is to use lagged values of explanatory variables and results are exhibited in column (2).

We note that the use of one-period lag of explanatory variables increases the explanatory power to $70 \%$. We also observe that the size and the significance of the previous estimated coefficients have increased. For instance, the coefficient of GSP is still negavtive but now statistically significant at the $5 \%$ level. This means that a $1 \%$ increase in gas production shrinks economic growth roughly by $1 \%$. Concerning the coefficient of GSU, its magnitude is now 0.74 and displays the highest level of significance. In other words, this suggests that a $1 \%$ increase in gas utilization, the level of economic growth expands by $0.74 \%$. As found previously, the coefficients of GSF and GCF are still insignificant albeit positive.

\section{Conclusion and Recommendations}

The main objective of this study is to examine the impact of the gas production, gas use and gas flaring on economic growth of the Republic of Congo during the period 2006-2019. The results of the unit root test reveal that the bulk of va- 
riables are stationary at level and therefore integrated of order zero, however, labor input is stationary at first difference and integrated of order one. The test of Johansen cointegration shows that all time series are cointegrated and have a long-run equilibrium relationship. We also perform the Granger-causality test which proves that only gas production and gas utilization cause economic growth in our study. The OLS regressions suggest that gas production impacts adversely and significantly GDP while gas utilization significantly stimulates GDP. This result implies that gas utilization is more influential than gas production for economic growth of the Republic of Congo under the period of study. Moreover, after the production of gas, this latter should be well used for influential economic activities.

Given that gas utilization depends on gas production, there is an urge need to improve gas production capacity in the Republic of Congo, while reducing the volumes of gas flared. To do so, we suggest the following recommendations to the Congolese government:

1) Encourage the use of gas in various fields such as: hospital, domestic (LPG).

2) Put in place fiscal/tariff policies to encourage oil operators to take an interest in gas exploitation, facilitate new investors in the gas sector.

3) Strengthen the existing legal framework, more specifically, the Hydrocarbons Code (No. 2016-28), section 2 flaring of associated gas: Articles 136 and 137 deal with the modalities and authorizations of gas flares in the oil industries Ministry of Hydrocarbons (2020).

\section{Acknowledgements}

The authors are thankful to Prof. Zhang Xingping as the supervisor of the corresponding author for providing the necessary assistance. However, all errors in this paper are our own.

\section{Conflicts of Interest}

The authors declare no conflicts of interest regarding the publication of this paper.

\section{References}

Afrik.com.

https://www.google.com/amp/s/www.afrik.com/cop21-le-congo-en-chef-de-file-des-pa ys-africains\%3Famp

Akan, Y., Dogan, M., \& Isık, C. (2010). The Causality Relationship between Energy Consumption and Economic Growth: The Case of Turkey. Enerji, Piyasa ve Düzenleme, 1, 101-120.

Akpan, S. (2009). The Production and Utilisation of Natural Gas Resources in Nigeria: A Review. The Nigerian Annual International Conference and Exhibition, Abuja, 3-5 August, 3 p. https://doi.org/10.2118/128356-MS

Alexeev, M., \& Conrad, R. (2009). The Elusive Curse of Oil. Review of Economics and Statistics, 91, 586-598. https://doi.org/10.1162/rest.91.3.586

Altinay, G., \& Karagol, E. (2005). Electricity Consumption and Economic Growth: Evi- 
dence from Turkey. Energy Economics, 27, 849-856.

https://doi.org/10.1016/j.eneco.2005.07.002

Augustine, O. I., \& Sanford, W. W. (1976). The Effects of Waste Gas Flares on the Surrounding Vegetation in South-Eastern Nigeria. Journal of Applied Ecology, 13, Article ID: 177187. https://doi.org/10.2307/2401936

Bartleet, M., \& Gounder, R. (2010). Energy Consumption and Economic Growth in New Zealand: Results from Trivariate and Multivariate Models. Energy Policy, 38, 3508-3517. https://doi.org/10.1016/j.enpol.2010.02.025

Bowden, N., \& Payne, J. E. (2008). The Causal Relationship between U.S. Energy Consumption and Real Output: A Disaggregated Analysis. Journal of Policy Modeling, 31, 180-188. https://doi.org/10.1016/j.jpolmod.2008.09.001

BP (2012). BP Statistical Review of World Energy. Canadian Public Health, Harmful Effects of Flaring on Human Health.

Collins, C., \& Oshodi, O. (2010). Improper Abandonment of Oil. Nigerians in America. http://www.nigeriansinamerica.com/articles/4403/1/Improper-Abandonement-Ofil/Pa ge1.html

Corden, W. M., \& Neary, J. P. (1982), Booming Sector and Deindustrialization in a Small Open Economy. Economic Journal, 92, 825-848. https://doi.org/10.2307/2232670

Davis, G. (1995). Learning to Love the Dutch Disease: Evidence from the Mineral Economies. World Development, 23, 1765-1779.

https://doi.org/10.1016/0305-750X(95)00071-J

Delacroix, J. (1977). The Export of Raw Materials and Economic Growth: A Cross-National Study. American Sociological Review, 42, 795-808. https://doi.org/10.2307/2094867

Ebohon, O. J. (1996). Energy, Economic Growth and Causality in Developing Countries. A Case Study of Tanzania and Nigeria. Energy Policy, 24, 447-453.

https://doi.org/10.1016/0301-4215(96)00027-4

Elvidge, C. D., Ziskin, D., Baugh, K. E., Tuttle, B. T., Ghosh, T., Pack, D. W., Erwin, E. H., \& Zhizhin, M. (2009). A Fifteen Year Record of Global Natural Gas Flaring Derived from Satellite Data. Energies, 2, 595-622. https://doi.org/10.3390/en20300595

Energy Sector Management Assistance Program (2001). African Gas Initiative: Main Report. Joint UNDP/World Bank Energy Sector Management Assistance Program.

Fadiran, G., Adebusuyi, A. T., \& Fadiran, D. (2019). Natural Gas Consumption and Economic Growth: Evidence from Selected Natural Gas Vehicle Markets in Europe. Energy, 169, 467-477. https://doi.org/10.1016/j.energy.2018.12.040

Frankel, J. A. (2010). The Natural Resource Curse: A Survey. HKS Faculty Research Working Paper Series, RWP10-005, John F. Kennedy School of Government, Harvard University. https://doi.org/10.3386/w15836

Halicioglu, F. (2007). Residential Electricity Demand Dynamics in Turkey. Energy Economics, 29, 199-210. https://doi.org/10.1016/j.eneco.2006.11.007

Herb, M. (2005). No representation without Taxation? Rents, Development and Democracy. Comparative Politics, 37, 297-317. https://doi.org/10.2307/20072891

Hill, R., Moore, J., Boone, D., \& Randall, C. (1985). Associated Gas Utilisation with Liquid Recovery. The Offshore Technology Conference, Houston, 6-9 May 1985, 10 p. https://doi.org/10.4043/5039-MS

Hirschman, A. O. (1958). The Strategy of Economic Development. New Haven, CT: Yale University Press.

Indexmundi Data (2019). Africa Proved Reserves of Natural Gas. 
https://www.indexmundi.com/map/?t=0\&v=98\&r=af\&l=en

Issik, C. (2010). Natural Gas Consumption and Economic Growth in Turkey: A Bound Test Approach. Energy Systems, 1, 441-456. https://doi.org/10.1007/s12667-010-0018-1

Jebli, M. B., Youssef, S. B., \& Ozturk, I. (2014). The Role of Renewable Energy Consumption and Trade: Environmental Kuznets Curve Analysis for Sub-Saharan Africa Countries. MPRA Paper, No. 54300.

Karl, K. L. (1997). The Paradox of Plenty: Oil Booms and Petro-States. Berkeley, CA: University of California Press. https://doi.org/10.1525/9780520918696

Kebede, E., Kagochi, J., \& Jolly, C. M. (2010). Energy Consumption and Economic Development in Sub-Sahara Africa. Energy Economics, 32, 532-537. https://doi.org/10.1016/j.eneco.2010.02.003

Kouakou, A. K. (2011). Economic Growth and Electricity Consumption in Côte d'Ivoire: Evidence from Time Series Analysis. Energy Policy, 39, 3638-3644. https://doi.org/10.1016/j.enpol.2011.03.069

Lee, C. C., \& Chang, C. P. (2007). Energy Consumption and GDP Revisited: A Panel Analysis of Developed and Developing Countries. Energy Economics, 29, 1206-1223. https://doi.org/10.1016/j.eneco.2007.01.001

Lise, W., \& Montfort, K. V. (2007). Energy Consumption and GDP in Turkey: Is There a Cointegration Relationship? Energy Economics, 29, 1166-1178.

https://doi.org/10.1016/j.eneco.2006.08.010

Madueme, S. (2010). Economic Analysis of Wastages in the Nigerian Gas Industry. International Journal of Engineering Science and Technology, 2, 618-624.

Mastorakis, N., \& Yazdi, S. (2014). Natural Gas Consumption and Economic Growth in Iran. In Advances in Environmental Technology and Biotechnology (pp. 1656-172). https://www.researchgate.net/publication/308748423 Natural gas consumption and economic growth in Iran

Mawussé, K. N. O. (2009). Consommation d'énergies et croissance du PIB dans les pays de l'UEMOA: Une analyse en données de panel. MPRA Paper, No. 15521.

Mensah, J. T. (2014). Carbon Emissions, Energy Consumption and Output: A Threshold Analysis on the Causal Dynamics in Emerging African Economies. Energy Policy, 70, 172-182. https://doi.org/10.1016/j.enpol.2014.03.038

Michaels, G. (2007). The Long Term Consequences of Resource Based Specialization, CEPR 6028. London: Centre for Economic Policy Research.

Ministry of Hydrocarbons (2020). Gas Data. Nigeria: Gas Flaring Wrecking Delta Communities.

Nankani, G. (1980). Development Problems in Nonfuel Mineral Exporting Countries. Finance and Development, 17, 6-10. https://doi.org/10.5089/9781616353407.022

Nurske, R. (1958). Trade Fluctuations and Buffer Policies of Low-Income Countries. Kyklos, 11, 141-154. https://doi.org/10.1111/j.1467-6435.1958.tb02361.x

Oh, W., \& Lee, K. (2004). Energy Consumption and Economic Growth in Korea: Testing the Causality Relation. Journal of Policy Modeling, 26, 973-981.

https://doi.org/10.1016/j.jpolmod.2004.06.003

Ouedraogo, I. M. (2010). Electricity Consumption and Economic Growth in Burkina Faso: A Cointegration Analysis. Energy Economics, 32, 524-531. https://doi.org/10.1016/j.eneco.2009.08.011

Paul, S., \& Bhattacharya, R. N. (2004). Causality between Energy Consumption and Economic Growth in India: A Note on Conflicting Results. Energy Economics, 26, 977-983. 
https://doi.org/10.1016/j.eneco.2004.07.002

Philippot, L. M. (2010). Natural Resources and Economic Development in Transition Economies. PRES de Clermont University Working Paper.

Prebisch, R. (1950). The Economic Development of Latin America and Its Principal Problems. New York: Lake Success.

Reno, W. (1995). Corruption and State Politics in Sierra Leone. New York: Cambridge University Press.

Ross, M. (2001). Does Oil Hinder Democracy? World Politics, 53, 325-361. https://doi.org/10.1353/wp.2001.0011

Ross, M. L. (1999). The Political Economy of the Resource Curse. World Politics, 51, 297-322. https://doi.org/10.1017/S0043887100008200

Sachs, J. D., \& Warner, A. M. (1997). Natural Resource Abundance and Economic Growth. NBER Working Paper No. 5398.

Sachs, J., \& Warner, A. (1995). Natural Resource Abundance and Economic Growth. In G. Meier, \& J. Rauch (Eds.), Leading Issues in Economic Development. New York: Oxford University Press.

Sala-i-Martin, X., \& Subramanian, A. (2003). Addressing the Natural Resource Curse: An Illustration from Nigeria. IMF Working Paper WP/03/139. https://doi.org/10.3386/w9804

Secretariat of the Convention on Biological Diversity, Brochure Entitled The Initiative Global Taxonomic.

Singer, H. W. (1950). The Distribution of Gains between Investing and Borrowing Countries. American Economic Review, 40, 473-485.

Smith, B. (2004). Oil Wealth and Regime Survival in the Developing World, 1960-1999. American Journal of Political Science, 48, 232-246. https://doi.org/10.1111/j.0092-5853.2004.00067.x

Songur, M., Muratoğlu, G., \& Muratoğlu, Y. (2016). Natural Gas Production and Economic Growth in Eurasian Countries: Evidence from a Panel ARDL Model. Bulletin of Energy Economics, 4, 155-162.

Soytas, U., \& Sari, R. (2003). Energy Consumption and GDP: Causality Relationship in G-7 Countries and Emerging Markets. Energy Economics, 25, 33-37. https://doi.org/10.1016/S0140-9883(02)00009-9

Soytas, U., \& Sari, R. (2007). The Relationship between Energy and Production: Evidence from Turkish Manufacturing Industry. Energy Economics, 29, 1151-1165. https://doi.org/10.1016/j.eneco.2006.05.019

Statistical Review of Word Energy (2020). 69th Edition. https://www.bp.com/content/dam/bp/business-sites/en/global/corporate/pdfs/energy-e conomics/statistical-review/bp-stats-review-2020-full-report.pdf

Tompson, W. (2006). A Frozen Venezuela? The "Resource Curse" and Russian Politics. In M. Ellman (Ed.), Russia's Oil and Natural Gas: Bonanza or Curse? (pp. 189-212). London: Anthem. https://doi.org/10.7135/UPO9781843317555.010

Total (n.d.). Reducing the Flaring of Associated Gas.

Wei, W. (2002). Study on the Determinants of Energy Demand in China. Journal of Systems Engineering and Electronics, 13, 17-23.

Wheeler, D. (1984). Sources of Stagnation in Sub-Saharan Africa. World Development, 12, 1-23. https://doi.org/10.1016/0305-750X(84)90033-0 
Wolde, R. Y. (2005). Energy Demand and Economic Growth: The African Experience. Journal of Policy Modeling, 27, 891-903. https://doi.org/10.1016/j.jpolmod.2005.06.003

Wolde-Rufael, Y. (2004). Disaggregated Industrial Energy Consumption and GDP: The Case of Shanghai, 1952-1999. Energy Economics, 26, 69-75. https://doi.org/10.1016/S0140-9883(03)00032-X

Word Bank (2020). Global Gas Flaring Tracker Report. http://pubdocs.worldbank.org/en/503141595343850009/WB-GGFR-Report-July2020.p df 